\title{
Rebuttal
}

\section{Complex all the way down: Reply to David L. Scarnecchia's Viewpoint on objectives, boundaries, and rangeland carry- ing capacity}

\author{
EMERY ROE
}

Author is executive coordinator, Center for Sustainable Resource Development, College of Natural Resources, University of California, Berkeley.

Key Words: carrying capacity, range ecosystems, range management

First, the charge of unnecessary jargon. Have you ever noticed that when social scientists and policy analysts use their technical language and terms of art, they are accused of excessive jargon, but when natural scientists run on with sentences like

"A systematic approach to the animal-unit concept logically leads to concepts of livestock carrying capacity and livestock substitution ratios compatible with the multiple objectives and multiple management options characteristic of rangc livestock systems" (Scarnecchia 1990)

they think they are not talking jargon! The double standard is obvious: When I use "conception" and "theory" I am criticized for being vague; when Scarnecchia uses "conceptualized" and "variables" he thinks he is being crystal clear. He is unhappy with "meta-theory," yet readily commends "de-analysis." All of this is understandable, I suppose, as he seems more upset by jargonophilous journals that by the social science phobia and disciplinary hubris coursing through his Viewpoint (Scarnecchia 1998).

Second, let us look more closely at his terminology. What he "recommends are "defining objectives and boundaries," "clearly stated objectives," "specific objectives within specified boundaries," and "rigorous, objective-based concept design." To appreciate what really is being recommended, allow me to introduce another useful social science typology.

The well-known sociologist, Charles Perrow (1984), has developed a framework that improves our understanding of how to manage any system (ecological, social, technological). The typology's dimensions are two-fold: coupling and interaction. A tightly-coupled system is (1) highly time-dependent in not allowing for delays or unexpected contingencies; (2) fairly invariant in terms of the sequence of activities required (i.e., B depends upon A having happened first); (3) by and large inflexible in the way its objectives are achieved (not only is the sequence of specific activities restricted, but there is only one way to achieve the overall goal desired); and (4) characterized by little slack and resources available to tolerate delays, stoppages and the unexpected when they do occur. In loosely-coupled systems, delays are not only possible, but common; sequences of activities are by no means invariant (e.g., it does not much matter in a university when some course requirements are met before getting a degree); many ways to achieve a common goal are available; and sufficient slack exists to tolerate a degree of waste without imperiling system survival in the process. Both tightly- and loosely-coupled systems are, in turn, complexly or linearly interactive. Complexly interactive systems are those with unfamiliar, unplanned, or unexpected sequences of activities that often are not visible or comprehensible. The sequences in a linearly interactive system are by contrast more familiar and expected and are quite visible and comprehensible, even if unplanned or unintended. The dimensions of coupling and interaction produces a typology of 4 cells.

\begin{tabular}{cccc} 
& & \multicolumn{2}{c}{ Interaction } \\
Coupling & Tight & 1 & Complex \\
& & 3 & 2 \\
& & Losear & 3
\end{tabular}

Many range managers and scientists find themselves in Cells 2 and 4 situations, thinking they really are in the good old days of Cell 1. And there is no better example of Cell 1 thinking in a Cells 2 and 4 world than the linear, tightly-coupled thinking that drives Scarnecchia's ("Just-draw-the-line!") Viewpoint. No amount of Cell 1 hankcring for clear and defined objectives and borders is going to change one scintilla the fact that range scientists and managers are working in a world where range ecosystems are complexly interactive (i.e., causality is not at all clear) with all manner of dynamic loosely- and tightly-coupled processes, ecological and otherwise. Persistent failure to realize specific objectives and designs because of increasing complexity are met by Cell 1 thinkers with calls for ever more specific objectives and "rigorous" designs. In this way, Cell 1 thinkers have been caught up in a race to outdistance their own shadows. Once a great spectator sport on the back 40 , but no longer.

So, what should we be attending to instead? Clearly, we must have more appropriate ways of thinking about range ecosystens as they really are, which is what I was trying to do in my Viewpoint (Roe 1997). Scarnecchia recommends models; I go further. In Cells 2 and 4 situations, you need a very wide range of quantitative and qualitative methods in order to triangulate on and build your confidence about what is happening in the range ecosystem and management under study (Roe 1998).

You also need new theories to recast old concepts in a more 
timely light as well as to explain those new range developments which the old concepts were never intended to explain. Which leads me to Scarnecchia's disparagement of recasting carrying capacity as a theory of knowledge generation and change. Not only is such a theory possible, it already exists. The "high-reliability" approach to carrying capacity is developed and applied in several up-coming publications, including one in the Journal of Arid Environments (Roe et al. forthcoming; see also Roe forthcoming and Roe et al. forthcoming.a.).

Finally, I confess I was initially befuddled by Scarnecchia's driving a herd of cows into my paragraph. Did he really think that my argument implies a theory of the cow? Was this one more case of natural science condescension? A labored attempt at humor? But then I figured it out. It was just another instance of Cell 1 thinking at work. To see this, everywhere you read "cow" in his Viewpoint, substitute his "Draw-the-line-somewhere!" What a perfect example of reducing the complex to the simple.

\section{Literature Cited}

Perrow, C. 1984. Normal accidents: living with high risk technologies. Basic Books, N.Y.

Roe, E. 1997. Viewpoint: On rangeland carrying capacity. J. Range Manage. 50:467-472.

Roe, E. 1998. Taking Complexity Seriously. Kluwer Academic Publishers. Boston/Dordrecht/London.

Roe, E. Forthcoming. Except-Africa: remaking development, rethinking power. Transaction Publishers, N.J.

Roe, E., L. Huntsinger, and K. Labnow. Forthcoming. A high reliability pastoralism. J. Arid Environ. 38.

Roe, E., L. Huntsinger, and K. Labnow. Forthcoming. High reliability versus risk averse pastoralism. J. Environ. and Develop.

Scarnecchia, D.L. 1990. Concepts of carrying capacity and substitution ratios: a system viewpoint. J. Range Manage. 43:553-555.

Scarnecchia, D.L. 1998. Viewpoint: on objectives, boundaries, and rangeland carrying capacity. J. Range Manage. 